\title{
Need for adaptive solutions to food vulnerability induced by fish scarcity and unaffordability in Senegal
}

\author{
Djiga Thiao $^{1, *}$, Julie Leport ${ }^{2}$, Baba Ndiaye $^{3}$ and Adama Mbaye ${ }^{1}$ \\ ${ }^{1}$ Centre de Recherches Océanographiques de Dakar-Thiaroye, P.O. Box2241, Dakar, Senegal \\ ${ }^{2}$ Université de Toulouse 2 - Jean Jaurès, 5 allée Antonio Machado, 31100 Toulouse, France \\ 3 Agence Nationale de la Statistique et de la Démographie, P.O. Box116, Dakar RP Dakar, Senegal
}

Received 25 April 2017 / Accepted 20 June 2018

Handling Editor: James Wilson

\begin{abstract}
With a level of consumption among the highest in Africa (23.9 kg/person/year in 2013), Senegal is highly dependent on fish in terms of food security. There are many socio-economic factors that influence the importance of fish in the dietary habits of the population. However, because of the major changes that have gradually occurred in the fishing sector during the last two decades in terms of fishing overcapacity and overexploitation, the availability of fish has become an increasing challenge. In this article, we document the particular case of Senegal as a good example of how food vulnerability can result from the scarcity and increasing price of fish products. Using average monthly prices of four major fish products and a consumer price index time series from 1998 to 2014, in combination with information collected from the literature and the field, we demonstrate evidence of fish scarcity and analyze the temporal structure of fish product affordability. Before exploring the potential solutions, we outline the major drivers of shortage of fish in the country and the resulting responses of the most vulnerable groups of the population. Considering the global and national context, the main constraints and challenges for efficient adaptive strategies are also identified.
\end{abstract}

Keywords: Fish / scarcity / affordability / vulnerability / food security / Senegal

\section{Introduction}

Located on the Atlantic coastal area of Western Africa, Senegal is a developing country where the fishing sector is one of the main pillars of the economy and social development. More specifically, this sector, which provides a considerable source of animal proteins, plays a major and vital role in the country's food security. The level of fish consumption in Senegal is among the highest in Africa. Therefore, the Senegalese population depends strongly on fish, which is part of most daily dishes.

Because of a poor fisheries management system that could not avoid generalized overexploitation of many species in a context of a growing national and global seafood demand, it is becoming more difficult to provide an adequate supply of fish for the Senegalese population. This growing structural crisis is characterized by increasing fish scarcity in the local markets, in combination with generalized rising fish prices. The consequences of this situation in terms of national food vulnerability and adaptive responses are not well documented. Moreover, the social, economic, and political challenges, and

\footnotetext{
*Corresponding author: d_thiao@yahoo.fr
}

their implications for sustainable fisheries management, need to be addressed.

In addition to supplementary information from a literature review, our study was mainly based on quantitative and qualitative analysis of fish price statistics and field socioanthropological information. First, we demonstrate the strong dependence of the Senegalese population on fish. Then we investigated the structural fish scarcity and unaffordability in Senegal in relation to overexploitation of the major fish stocks. Having highlighted the main adaptive dietary responses of the population to maintain adequate levels of fish consumption, we propose some potential solutions, while mentioning their associated constraints. Finally we discuss the challenges related to fish scarcity and unaffordability by emphasizing the demographic drivers of fish shortage, the pessimistic perspectives on world fish availability, the unfavorable purchasing power of the population, and the risk of greater inequity in fish accessibility.

\section{Materials and methods}

\subsection{Determination of the consumer price index}

In Senegal, the evaluation of the inflation level is based on a permanent process of data collection and analysis of the 
consumer price index (CPI). For this purpose, monitoring is regularly performed at different places on the retail prices of goods purchased by households in order to satisfy their needs and personal desires.

The monitoring of consumer prices is under the responsibility of the National Agency for Statistics and Demography. However, this monitoring is implemented through a regional framework including a standardized methodology used by the eight member states of the West Africa Economic and Monetary Union (UEMOA, 1996). This framework guarantees the same approach in measuring and interpreting a common Harmonized Consumer Price Index (HCPI) in the different countries. Price data collection is conducted in various reference places located both in urban and rural areas, including open markets, supermarkets, shops, etc. For each product, the average monthly price and the CPI are computed by the National Agency of Statistics and Demography. For any time period under consideration $(t)$, the CPI $\left(I_{t}\right)$ of a given product $i$ is calculated through the formula below (Eq. (1)) by considering $P_{0}$ and $Q_{0}$ as respectively the price and the quantity of the reference period, and $P_{t}$ the current price.

$$
I_{t}=\frac{\sum P_{t, i} Q_{0, i}}{\sum P_{0, i} Q_{0, i}} .
$$

This CPI is based on the Laspeyres price index for which the quantity is expected to be unchanged over the reference period. For this reason, when consumption habits change significantly compared to the reference period, the UEMOA countries have to conduct a frame survey to update the quantity and set up a new base where CPI $=100$ (UEMOA, 1996). Between two adjacent periods $t$ and $t+1$, the inflation level $\left(F_{t}\right)$ is the variation rate of the CPI (Eq. (2)).

$$
F_{t}=\frac{I_{t+1}-I_{t}}{I_{t}} .
$$

\subsection{Analysis of changes in fish prices}

Using average monthly prices, we first analyzed changes in the time series from 1998 to 2014. The price data are in CFAF (CFA Franc) which is the currency used by the eight member states of the West Africa Economic and Monetary Union (1 Euro $=655.957 \mathrm{CFAF})$. We focused on four main fish products that had been the most regularly monitored by the National Agency of Statistics and Demography for several years. These fish products are also among the most consumed in Senegal. They comprised fresh Sardinella (Sardinella aurita and Sardinella maderensis), fresh Red pandora (Pagellus bellottii), smoked Sardinella and dried fish. The monthly monitoring of these four fish products enabled us to describe short-term variations in the average fish price. It also gave us an overview of the long-term trends, and the potential presence of seasonal fluctuations.

The second step of the analysis consisted in estimating the trend and the seasonality of the fish products. The analysis was done on the fish annual CPI time series $\left(I_{t}\right)$ from 1998 to 2014, on which we applied a linear regression to estimate the trend as indicated below (Eq. (3)), where $\alpha$ and $\beta$ are the coefficients of the regression and $\varepsilon$ represents the residuals.

$$
I_{t}=\alpha+\beta * t+\epsilon \text {. }
$$

The slope $\beta$ represents an estimation of the absolute annual variation of the CPI (Eq. (4)). This gives us an overall idea of the long-term magnitude of fish product affordability over the period 1998-2014.

$$
\frac{\Delta I_{t}}{\Delta t}=\beta .
$$

To deepen the analysis on the magnitude and long-term fish affordability, we compared the CPI for fish $\left(I F_{t}\right)$ with the CPI for all goods and services $\left(I G_{t}\right)$. For this purpose, we applied the same above linear regression (Eq. (3)) on both time series. The trends estimated for $I F_{t}$ and $I G_{t}$ were also plotted in the same figure in order to facilitate the comparison.

To analyze the seasonality of fish affordability, we calculated the 12 monthly average values of the CPI from 1998 to 2014 . The purpose was to identify the period of the year where fish prices are at their highest or lowest levels. This was essential to better understand the seasonal vulnerability of consumers regarding the variability of fish abundance and availability on local markets. For each month $j$, the seasonal CPI $\left(S_{j}\right)$ was determined as below (Eq. (5)). Here, $I_{j t}$ corresponds to the average CPI for month $j$ in a given year $t$. For each of the 12 seasonal values, we also plotted the standard deviation in order to visualize its variability.

$$
S_{j}=\frac{1}{17} \sum_{t=1}^{17} I_{j t}
$$

\subsection{The socio-anthropological fish consumption survey}

In addition to the fish price data, our study was also based on a socio-anthropological survey conducted in 2013-2014 for a $\mathrm{PhD}$ thesis on food dynamic changes (Leport, 2017). For this approach, both qualitative and quantitative approaches were adopted. The qualitative approach included 29 individual semi-structured interviews and 22 participatory observations of the whole process of food supply, preparation and consumption in selected households. All interviews and observations took place in areas of the region of Dakar that were selected for their socio-economic diversity. In addition, some complementary discussions about the problem of fish availability were also conducted with a group of women involved in the day-to-day management of households, including meal preparation. This qualitative approach allowed us to identify changes in behavior in terms of dietary responses. After this first qualitative step, a second quantitative approach was carried out to clarify the results on the adaptive responses previously observed. A questionnaire was used to survey 800 inhabitants of the region of Dakar selected through the method of cross-quota sampling considering three variables (age, sex and residential area) according to the latest census of 2002. The survey was conducted by a team of investigators in either Wolof or French, depending on the language in which the respondent was most comfortable. 
Despite the relatively low number of people and households interviewed as a proportion of the total nation population, this qualitative and quantitative fish consumption survey helped us to understand the issues of food vulnerability due to fish scarcity and unaffordability, and how sampled consumers adapted to these new realities. We noted that most of the results obtained from the survey support our observations on the field, particularly in the large cities of Senegal.

\subsection{Collection and analysis of complementary data}

In addition to the fish price time series, we gathered and analyzed complementary data that helped us to better understand the issue, magnitude and drivers of fish scarcity and unaffordability. The first category of complementary data was a 30-year time series (1987-2016) of the total population and urbanization ratio of Senegal. These two demographic indicators widely known in the literature to be major drivers of fish consumption were extracted from the World Bank online database (http://data.worldbank.org/country/senegal). We also collected and analyzed a 26-year time series (1990-2015) of aquaculture production in Senegal that we compared with the national fisheries catch over the same period. The purpose was to show the recent progress of the aquaculture sub-sector, and the associated gaps and constraints of its potential contribution to the satisfaction of domestic fish demand. Like the demographic indicators, the aquaculture and fisheries data were also collected from the World Bank online database (http://data.worldbank.org/country/senegal).

\section{Results}

\subsection{Fish and food security in Senegal}

\subsubsection{The nutritional importance of fish}

Until the early 2000 s, fish provided approximately $75 \%$ of the animal protein consumed in the country (UNEP, 2002; Failler and Lecrivain 2003). However, more recent figures from the Food and Agriculture Organization (FAO) (http:// www.fao.org/fishery/facp/SEN/en) indicate a much lower proportion of $43 \%$ in 2013 . In addition to fish scarcity, this decrease in proportion may be as a result of diversification of the sources of animal proteins such as meat, chicken and eggs, whose availability and affordability have been improving in the country. Nevertheless, along the coastal area where the majority of the population resides, the proportion of fish in animal protein remains high, and can even exceed $80 \%$ in some areas. According to the literature, the Senegalese population is one of the largest fish consumers in Africa. In the particular case of West Africa, Senegal had the highest level of fish consumption (Fig. 1) with $25.9 \mathrm{~kg} /$ person/year against for example $17.5 \mathrm{~kg} /$ person/year in Ghana and only $5.7 \mathrm{~kg} /$ person/year in the neighboring Mauritania (Lam et al., 2012). However, this ratio has been decreasing since the nineties (from 36.5 in 1993 to $23.9 \mathrm{~kg} /$ person/year in 2013) (http://www.fao.org/fishery/facp/SEN/en). Apart from some small pelagic species, fish is now generally more expensive than chicken and meat that are also currently more available in the market because of the increasing domestic production

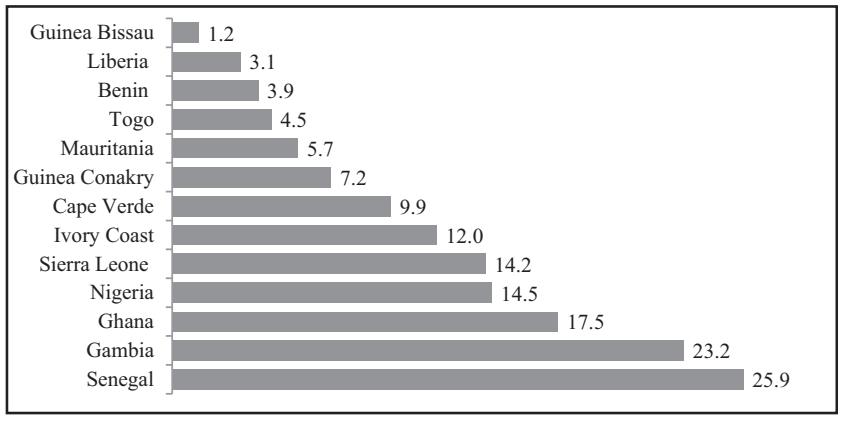

Fig. 1. Average per capita fish consumption in the coastal West African countries (in $\mathrm{kg} /$ person/year).

and import. However, consumed on a daily basis, fish is still part of most national dishes. Although availability is higher in the coastal area of the country, the inland zone is also relatively well-supplied in fresh fish through refrigerated trucks. Being easy to transport and store, dried or smoked fish are also very popular in the inland localities.

\subsubsection{The socio-cultural role of fish}

In Senegal, the popular appreciation for fish is not only due to nutritional opportunism. Fish is also part of the main drivers of social cohesion in many Senegalese communities (Leport, 2017). For instance, in the coastal area, the social organization is strongly influenced by fishing activities. Therefore, selling and donating fish fosters and consolidates social links between families. Moreover, for the coastal communities whose culture and traditions are essentially based on fishing activities, the daily availability of fish contributes to strengthening of the collective identity of the group. More generally, even though fish consumption is certainly influenced by nutritional and economic reasons, it also strongly depends on the dietary preferences and thus on the culinary considerations of the communities (Poulain, 2002). This is why in Senegal, a very popular combination of rice and fish called ceebu jen in the local language is commonly considered as the main dish that has become a significant element of the national identity. It is always part of the daily menu of most households and restaurants. In addition to this famous ceebu jen, fish is a component of several other national and local dishes such as yassa and fried fish that are also very popular in the country.

\subsubsection{The main consumed fish species in Senegal}

Fish products consumed in Senegal are essentially landed by the artisanal fisheries. While the demersal species are less abundant, very expensive and export-oriented (Thiao and Laloë, 2012; Thiao et al., 2012), the small pelagic species are the major component of the fish consumption. In the 2000s, about $85 \%$ of the small pelagic fish landings were sold in the local markets (Failler and Lecrivain, 2003). However a decade later, this percentage has dropped down to $60.7 \%$ in 2013 (http://www.fao.org/fishery/facp/SEN/en) probably because of increasing exports to other African countries and the development of local fishmeal production that mainly focuses on Sardinella species. Regarding the level of the catch in recent years, this percentage corresponds to approximately 


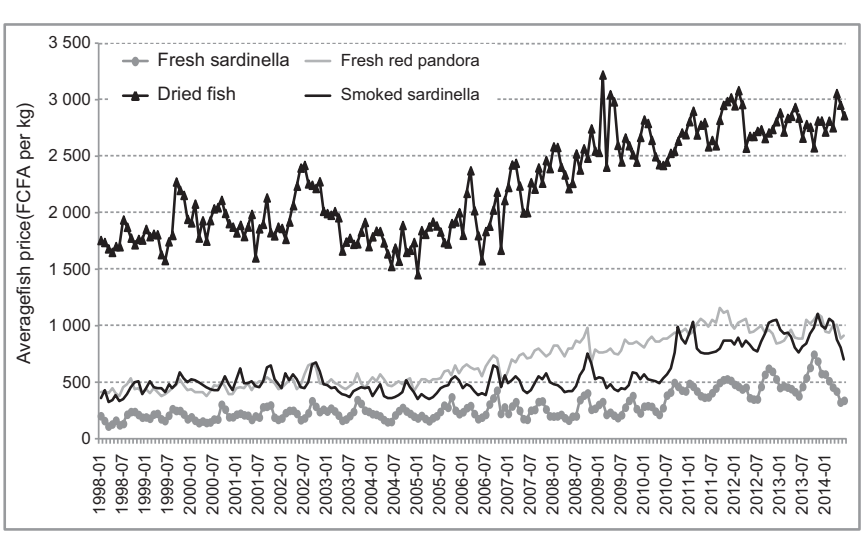

Fig. 2. Monthly average price of the main consumed fish products in Senegal from 1998 to 2014 (in FCFA $/ \mathrm{kg}$ ).

235000 tonnes of small pelagic fish consumed annually in Senegal representing about $14.5 \mathrm{~kg} /$ person/year (http://www. fao.org/fishery/facp/SEN/en). Among these small pelagic fish, only three species essentially make up almost the entire production and consumption. These are round Sardinella (Sardinella aurta), flat Sardinella (S. maderensis), and Bonga shad (Ethmalosa fimbriata). Fresh, dried or smoked, the three species are the only ones available all year round in most of the localities in Senegal.

\subsection{Fish scarcity and unaffordability in Senegal}

\subsubsection{Evidence of fish scarcity}

Despite its vital importance for food security in Senegal, the fishing sector is facing a crisis resulting from generalized overexploitation of the major fish stocks. This context that has been threatening the sustainability of the sector and the living conditions of the population has been stressed by several authors since the early 2000s (Christensen et al., 2002; Laurans et al., 2004). Moreover, all the recent scientific working groups of the Committee of the Eastern-Central Atlantic Fisheries (CECAF) have raised concerns about the generalized overexploitation of the main fish stocks in the whole Northwest Africa marine area. For the particular case of demersal species, the situation which was already of concern for several years has now worsened. A risk of extinction has even been discussed for some species like white grouper Epinephelus aeneus, which is very emblematic in Senegal (Thiao et al., 2012). Regarding the small pelagic species whose situation was stable for years, the current level of exploitation is now considered critical (FAO, 2015). In addition to often destructive fishing practices, the degradation of marine resources is mainly due to ineffective fisheries management, which is unable to regulate the heavy fishing pressure resulting from structural overcapacity.

\subsubsection{The generalized rising fish prices}

During the last two decades, the main fish products in Senegal have been characterized by generalized rising prices with strong fluctuations (Fig. 2). Considering fresh Sardinella, which is the most affordable and also the most consumed fish

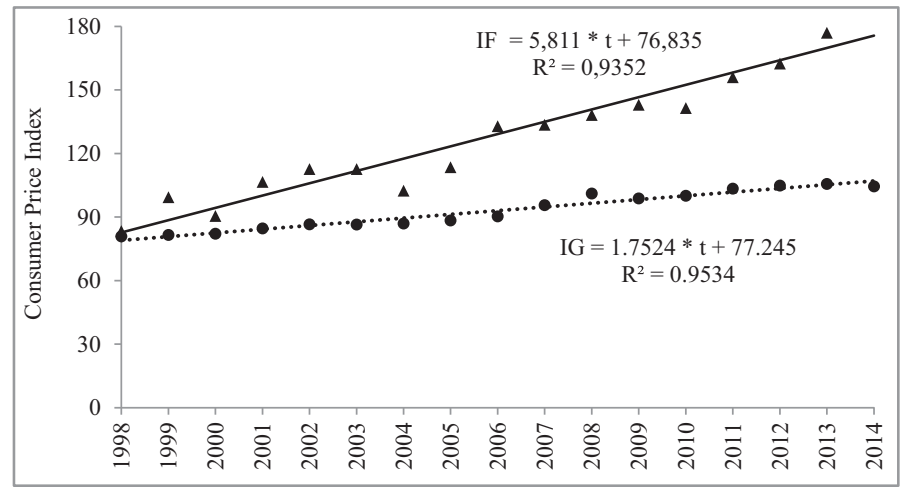

Fig. 3. Long-term linear trends of the consumer price index for fish ( $I F$, in full line) and for all goods and services ( $I G$, in broken line) from 1998 to 2014 in Senegal.

product in the country, the price has more than doubled during the last 17 years (from about $200 \mathrm{FCFA} / \mathrm{kg}$ in 1998, the price has been around 500 FCFA $/ \mathrm{kg}$ since 2010). However, for a long time, the price of fresh Sardinella remained relatively low and stable before going through a phase of rising prices starting from the second half of the 2000s. During the last decade, the price has been marked by considerable variability due to the recent instability of its availability. Smoked Sardinella which is relatively more expensive than fresh Sardinella has also had a similar price evolution. From less than 500 FCFA/kg in 1998, the price of smoked Sardinella reached a peak of 1000 FCFA/ $\mathrm{kg}$ in 2013.

Regarding fresh Red pandora, the price also increased considerably from 1998 to 2014. From less than 500 FCFA/kg at the beginning of this period, it exceeded $1000 \mathrm{FCFA} / \mathrm{kg}$ after 2011. The upward trend in the price of Red pandora has also been more significant since the beginning of the second half of the 2000s. For instance, it doubled in a short period of 5 years, from 2005 to 2011. Dried fish is another very important product in Senegal because in the context of lack of transportation and storage infrastructures, it has the advantage of being very easy to store for a long time both in urban and rural areas. It is also often considered as a substitute product during the shortage of fresh fish. Because of these two important factors, dried fish is usually characterized by high and fluctuating prices (Fig. 2). From around $2000 \mathrm{FCFA} / \mathrm{kg}$ during the first decade of 1998-2014, the price of dried fish quickly increased to above $3000 \mathrm{FCFA} / \mathrm{kg}$ in 2009 . However, during the last five years of the time series, the price stabilized to between $2500 \mathrm{FCFA} / \mathrm{kg}$ and $3000 \mathrm{FCFA} / \mathrm{kg}$.

\subsubsection{Long-term trends for the fish consumer price index}

In addition to the average monthly prices of the four main fish products analyzed above, the linear regression on the CPI validates the hypothesis of a significant linear upward trend during the last two decades (Fig. 3). The estimated slope indicated that the CPI for fish has increased considerably at an average of 5.8 points per year $\left(R^{2}=93.5 \% ; R^{2}\right.$ Adjusted $=$ 93.1\%; $F=216.4$ and Significance $=0.000$ ). Because of this very rapid increase in rhythm, from 83 points in 1998 , the CPI for fish was multiplied by 2.3 to reach 190 points in 2014 . 


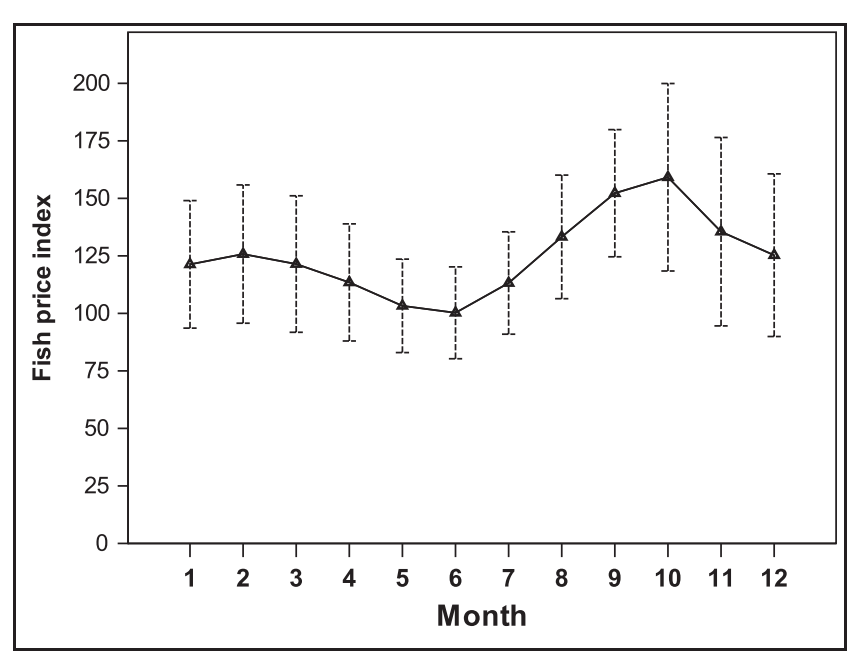

Fig. 4. Seasonal variability of the consumer price index (CPI) for fish in Senegal.

Compared to the CPI for all goods and services, we can see that during the last two decades, the CPI for fish was not only higher, but it also increased much more rapidly. With a slope of 1.7, the long-term trend of the CPI for all goods and services $\left(R^{2}=95.3 \% ; R^{2}\right.$ Adjusted $=95.0 \% ; \quad F=306.8$ and Significance $=0.000$ ) shows that the increasing rhythm of the price of fish was at least three times greater. With such a trend, the affordability of fish will certainly become more and more concerning in the future.

\subsubsection{The seasonal variability of fish affordability}

The CPI for fish was characterized by significant seasonal variations over the period 1998-2014, with two opposite phases (Fig. 4). The first phase (April-July) corresponds to the annual period when the CPI is lower. During this season, which is characterized by strong upwelling events along the Northwest Africa coast, the abundance of most of the small pelagic and demersal species is generally high enough to improve fish supply to local markets. Therefore, fish products become more affordable and also, prices are more stable over the period (lower standard deviation) due to a greater and more regular supply of fish. On the other hand, from September to November, fish prices reach their highest levels also with considerable fluctuations over the period (higher standard deviation). In addition to the absence of upwelling events, this most difficult period of the year corresponds to the rainy season which is usually very unfavorable for fishing activities. Therefore, starting from August until November, fish affordability is usually very challenging in Senegal and most consumers face higher food vulnerability.

\subsection{Adaptive dietary responses of the population}

\subsubsection{Substitution between different fish products}

In a context of fish scarcity, the first rational option for the consumer is to substitute the products that have become inaccessible with other ones that are available and more affordable. Known to economists as "substitution", this is an adaptive response currently adopted by most households in order to maintain their fish consumption. However, this strategy is usually accompanied by a loss of quality. For instance, in the past, some favorite demersal fish like white grouper were progressively replaced by other less valuable demersal fish such as Seabream and Red pandora (Thiao, 2009). Then, when the latter become scarce and expensive, the population turned more and more to the small pelagic fish that are usually considered by most consumers be low quality products because they are bony, which makes them difficult to eat. In addition, some species that used to be rejected in the past are now being eaten by consumers. Moreover, substitution between fresh fish and dried or smoked fish is now also a very common practice, particularly in rural areas. The substitution strategy between different species and products has certainly resulted in a reduction in quality for the consumer, but this approach at least enables the population to maintain their favorite dishes made with fish (Leport, 2017).

\subsubsection{Diversification of animal proteins}

Meat, chicken and eggs are the animal products that have become important for the consumer in Senegal during the last decade because of the significant increase in domestic production and increased imports from neighboring and industrialized countries (Mankor, 2001; Leport, 2017). Therefore, the increased availability of these provides an opportunity to mitigate the vulnerability of the population to fish scarcity and unaffordability. However, this apparent opportunism towards other sources of animal proteins has many constraints. First, the socio-cultural attachment to fish is so strong that it is far from being replaceable by meat, chicken and eggs (Leport, 2017). For instance, for an annual fish consumption of about $25 \mathrm{~kg}$ per person, the value of this indicator is still limited to $13 \mathrm{~kg}$ for all kinds of meat. Moreover, meat, chicken and egg consumption is essentially concentrated in the wealthier households. Although it has become more abundant, meat still remains too expensive for the majority of households who even associated it with luxury. As an illustration, one $\mathrm{kg}$ of meat (beef or mutton) costs between 2500 and 3000 FCFA against only about 500 $1000 \mathrm{FCFA} / \mathrm{kg}$ for Sardinella fish. For most households, significant consumption of meat is often noted during special events or receptions for important guests.

\subsubsection{Changes in culinary habits}

Changes in culinary habits are also a common adaptive response adopted by many households that face fish scarcity and affordability (Leport, 2017). This strategy is based on the change in the quantity and the quality of daily meals. Regarding quantity, the Senegalese tradition encourages families to cook more food than is needed to be able to satisfy any unexpected guest. But this tradition of hospitality tends to disappear in a context of rising fish prices combined with costly living conditions. Therefore, most families have to reduce the quantity of fish in their meals. In terms of quality, many households usually forfeit essential elements such as vegetables in order to be able to buy fish necessary to maintain the national dish ceebu jen, even more importantly, poorer households choose the cheaper fish, which may be of lower quality. In some extreme but common situations, the 
poorest households eliminate one of their daily meals (dinner or breakfast) in order to be able to maintain rice and fish for lunch.

\subsection{Potential solutions and associated constraints}

\subsubsection{Implementation of effective fisheries management}

Effective fisheries management that stops overexploitation and fosters stock rebuilding is necessary to counteract fish scarcity in order to improve domestic fish supply in Senegal. Such a fisheries management system must address the current high fishing pressure. In addition, due to a lack of enforcement of regulatory measures related, for example, to the minimum mesh and fish size, it has become a priority to combat irresponsible fishing practices that are very common in Senegalese waters. Therefore, through an efficient comanagement system, the government, in collaboration with the local stakeholders and other partners, has to enhance the interventions in the fisheries sector through more ambitious and concrete actions. Management measures that could contribute to improve the situation in the fisheries sector should focus, among others, on eradication of the open access regime in favor of Territorial Use Rights for Fishing (TURF), establishment of spatial and/or seasonal closures in critical ecosystems, and law enforcement of the prohibition of destructive fishing gears and practices. Although there are some initiatives that are being implemented in this direction, very limited success has been obtained so far. Some major constraints mainly related to weak governance as well as high social and economic stakes, and political pressure, usually undermine the effectiveness of the fisheries management system in Senegal (Thiao et al., 2012; Bundy et al., 2017; Thiao et al., 2017). For instance, the government generally lacks enough determination to implement some necessary management measures and also to enforce the law.

An effective fisheries management would also require reconsidering the sub-regional context. In this case, stronger strategic relationships with the neighboring coastal West African countries are necessary. During the last decade, catches made by Senegalese fishers in the waters of neighboring countries have been significant enough to mitigate the fish shortage on the domestic market. For instance, during recent years bilateral agreements have allowed the Senegalese artisanal fishers to exploit small pelagic species in Mauritania. In addition, a significant proportion of demersal species landings has come from Guinea Bissau. Therefore, it is essential to find suitable ways to maintain this very beneficial external fish supply. However, because these countries are becoming reluctant to welcome guest fishers from Senegal, the only way to support and strengthen the relationships is to negotiate bilateral formal win-win fisheries agreements. Such agreements have to be mutually fair and beneficial, while effectively combating illegal, unregulated and unreported fishing in the whole sub-region. Senegal, which hosts the SubRegional Fisheries Commission, should make more efforts, in collaboration with the other six member states, to advocate for and leverage a context where it is possible to implement common fisheries management plans on transboundary fish stocks and negotiate collective fishing agreements with the EU, China and other foreign countries.

\subsubsection{Fostering responsible fish harvest and utilization}

Despite Article 11.1 of the FAO Code of Conduct for Responsible Fisheries related to the principle of responsible fish utilization (FAO, 1995) established two decades ago, seafood losses remain a serious problem, irrespective of the economic status of the country, the scale of the fisheries, or the supply chain complexity. The percentage of fish and seafood produced for human consumption lost or wasted globally is almost twice that of meat (FAO, 2017). In the particular case of Africa, there is $20-25 \%$ of fish post-harvest losses (FAO, 2016). For instance, in Ghana physical and quality losses from purse seine fisheries were respectively estimated at $16-20 \%$ and $30.7 \%$, and figures for smoked fish are $3-17 \%$ and $37.5 \%$ (Akande and Diei-Ouadi, 2010). Although there is a lack of data on fish losses and waste in Senegal, the magnitude is also likely to be considerable. Therefore, the improvement of fish availability and quality for human consumption in the country requires effective actions and measures on different postharvest segments of the supply chain in order to foster responsible fish utilization.

Post-harvest fish losses are often caused by several factors including mainly discard of bycatch at sea, poor processing techniques as well as inadequate handling, packaging, storage and transportation practices (Diei-Ouadi and Mgawe, 2011). Therefore, in Senegal, the first segment where interventions are needed is related to the capture operations at sea in order to significantly reduce discarded bycatch, more particularly in foreign and national demersal trawlers targeting specific species and/or precise size ranges. Here, it is necessary to enforce all regulations related for example to the minimal fish size, selectivity measures and seasonal closures in nursery areas. Since it seems impossible to completely eradicate bycatch, fishers also need to be made more aware and encouraged to keep and land their undesired catches that could be useful for consumption by the local population. Moreover, modernized efficient artisanal processing techniques are essential to reduce quantitative and qualitative fish losses. For instance, the introduction of improved smoking ovens and adequate drying racks to replace the traditional ones so far used for small pelagic fish smoking will significantly improve the availability of the very much appreciated smoked fish. Reducing the other post-harvest losses also requires adequate infrastructures and practices for landing, handling, packaging, storage and transportation of fresh and/or processed fish in the country. During recent years the Senegalese government has been making significant efforts in that direction, but considerable gaps still remain.

Another strategic focus to rationalize fish utilization in Senegal is to limit and effectively control the rapidly expanding fishmeal industry, whose production is essentially for export. Despite the lack of official information on this industry, data from the US Department of Agriculture Production, Supply, and Distribution online database (https://www.indexmundi.com/agriculture/?country=sn\&com modity=fish-meal\&graph=exports) show a spectacular increase in Senegalese fishmeal exports. From only 3000 metric tons in 2003 the quantity of exported fishmeal doubled in 2008 and then reached a peak of 17000 metric tons in 2014. This remarkable growth reflects generalized enthusiasm towards fishmeal production in many coastal West Africa countries, 


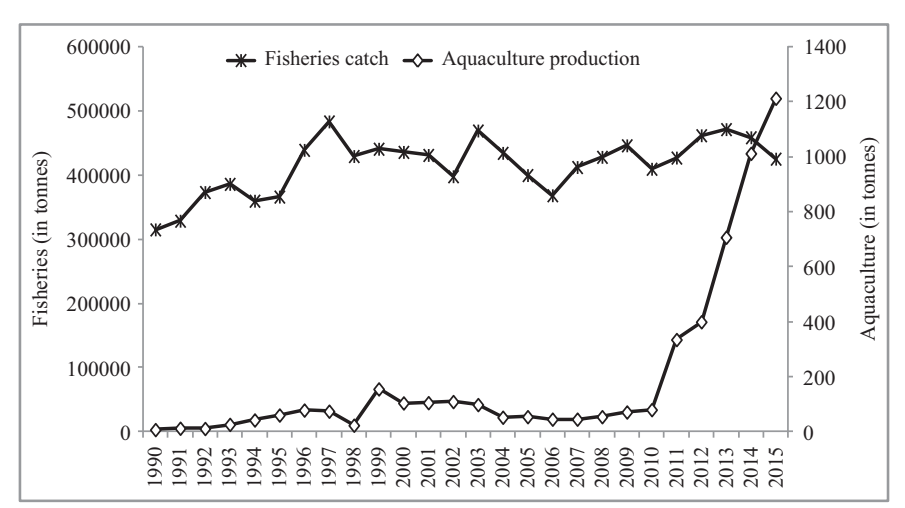

Fig. 5. Trends in aquaculture production in Senegal in comparison with the fisheries total catch from 1990 to 2015.

attracted by the very lucrative prices driven by strong rising demand in major foreign markets. According to the Coalition for Fair Fisheries Arrangements (http://www.cape-cffa.org/), in Senegal, there are a dozen officially registered fishmeal companies, and in Mauritania, the number had reached 29 in 2015, while 2 new ones had also been built in Gambia. Because fishmeal is used for the fast expanding aquaculture and livestock sectors, it may be a serious threat to human fish consumption in developing countries whose population will not be able to afford more and more expensive fish. In Senegal, where it is essentially oriented to the small pelagic species, particularly juvenile Sardinella, the fishmeal industry encourages overexploitation and poor fishing practices of socially strategic fish stocks. By competing with local consumer markets, it is also weakening food security for the poorest populations.

\subsubsection{Development of a productive aquaculture sector}

In addition to the fisheries, aquaculture has become a major contributor to fish supply globally. However, whereas fisheries catches are relatively static since the late 1980s, aquaculture production has been responsible for the impressive growth in the supply of fish for human consumption (FAO, 2016). With 73.8 million tonnes, worldwide aquaculture accounted for $44.1 \%$ of total production of fish in 2014 . Because aquaculture has become a key opportunity for revenue generation and food security, several African countries have been making more efforts to develop this sector. During recent years, aquaculture development has been considered a high priority by the Senegalese government. This political will has been expressed in several national policy guidelines like the Strategy of Accelerated Growth (since 2008), the National Strategy for Economic and Social Development (2013-2017), and more recently the Emerging Senegal Plan (2014-2018). Moreover, in order to better coordinate the identification and implementation of concrete initiatives in the field, the National Aquaculture Agency was created in April 2011.

The actions undertaken have significantly boosted aquaculture production in Senegal during recent years. Official available data (http://data.worldbank.org/country/senegal) show a considerable rising trend since 2011, while fisheries catches were decreasing (Fig. 5). In 2011, production was 334.7 tonnes, whereas it rarely exceeded 100 tonnes per year

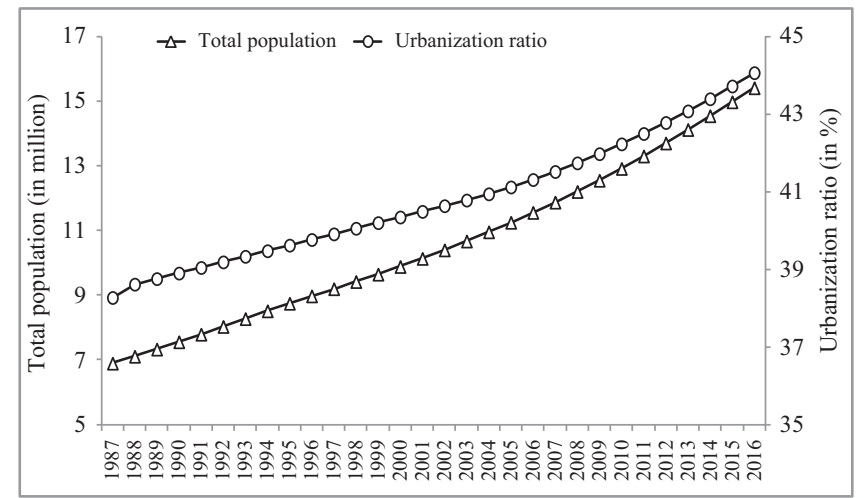

Fig. 6. Increase in total population and the urbanization rate in Senegal from 1987 to 2016.

beforehand. Five years later, it had almost quadrupled to reach 1212.5 tonnes in 2015. Despite this recent relatively impressive increase in production, the aquaculture sector is still very far from being able to play a considerable role against fish shortage in the country. Many constraints have to be overcome for aquaculture to make a real difference in fish production, among which: the lack of technical staff; gaps in scientific knowledge; and the lack of support and incentive measures for private partners. In addition, the high levels of investments required, the high operating costs, and the very low market share and profitability compared to capture fisheries are serious limiting factors. Moreover, technologies in aquaculture are still limited to a very few number of species including mainly tilapia and oyster. Also, massive aquaculture development in the future may increase national demand in fishmeal, which could aggravate the already serious situation of marine resources for the country, and also divert small pelagics that are important for low-income consumers from direct human consumption to fishmeal production for aquaculture.

\section{Discussion}

Population growth and urbanization are strong demand drivers of food, as well as changes in dietary preferences (Hall et al., 2011; Zuberi and Thomas, 2012). The quantity and quality of fish consumption and the associated prices are also sensitive to these two factors, particularly in Sub-Saharan African countries (Gordon et al., 2013). Like most of SubSaharan Africa countries, Senegal has experienced high levels of population growth and urbanization during the last three decades (Fig. 6). From 1987 up to 2016, the population increased by a factor of 2.2 from 6.9 million to 15.4 million inhabitants. The trend in population is quite exponential, with an annual growth rate varying between 2.3 and 3.0\%. The last 30 years (1987-2016) were also characterized by rapid urbanization in the country. In the mid-eighties, the urbanization rate was around $38 \%$. Thirty years after, the percentage of urban population in Senegal reached $44.1 \%$. Moreover, the urbanization rate has accelerated since the beginning of the 2000s. In a context of generalized fish scarcity, greater seafood needs will likely remain a major challenge in the future. Because of insufficient supply, rising national and international demand may also aggravate fish affordability in the country. 
During the last two decades, the globalization of markets, including removal of trade barriers and low-cost transport, has significantly affected the international flows and prices of fisheries and aquaculture products (Garcia and Grainger, 2005). The development of exports from production zones towards richer markets is a remarkable illustration of this recent context characterized by a considerable increase in world gross per capita fish consumption that increased from an average of $9.9 \mathrm{~kg} /$ person in the $1960 \mathrm{~s}$ to $20.1 \mathrm{~kg} /$ person in 2012 (FAO, 2016). However, despite the current high fishing pressure and aquaculture development, global fish production is still unable to satisfy the huge demand. The availably of fish for human consumption may become more critical in the future, particularly in developing countries. In Africa, in general, and in Senegal, in particular, it is expected that there will be a $10 \%$ decrease in fish per capita consumption by 2022 , due to the fact that the population growth will be higher than the rate of increase in fish supply. It is expected that the Senegalese domestic catches will be more intensively oriented to the overseas markets, especially to developed and emerging countries, while the average international fish price will increase by $30 \%$ in nominal value. As a result, most of the Senegalese population may not be able to afford the very limited quantity of fish that would be available in the local markets. This situation will likely reduce the adaptation capacity of the population and thus increase their vulnerability to seafood shortage. Recently, modeling the vulnerability to shocks in the global seafood trade network, Gephart et al. (2016) concluded that Central and Western African countries are the most vulnerable because of their very low capacity and willingness to pay more and more for expensive fish.

During the last decade, Senegal has made considerable progress in the fight against poverty. However, the country still remains among the poorest countries in the world with a low standard of living. According to the World Bank (http:// data.worldbank.org/country/senegal), the country is at the lower end of the intermediate income countries. The proportion of the population under the poverty threshold decreased only from $48.3 \%$ in 2005 to $46.7 \%$ in 2010 . This situation reflects the low purchasing power of most households that have to struggle every day to get enough food. Therefore, their ability to buy fish that will be more expensive may become very limited. Thus, they will be unable to adapt to the ongoing growing fish scarcity and unaffordability that is likely to raise national inequality in fish consumption. Gaps in terms of food vulnerability will become higher between wealthy and poor household as well as between urban and rural areas. Despite the current efforts at improving transport and storage infrastructures, the national fish supply will likely be concentrated in large coastal cities where wealthier households are present. Until the 1990s when fish was still very abundant, even the most remote villages were quite regularly well supplied with fresh fish through trucks and carts. Nowadays, even the availability of smoked or dried fish in these rural areas has become very limited. As a result, the risk of greater inequality in fish consumption may lead to malnutrition for a large part of the population that will lack animal proteins and other nutrients essential for human health and well-being.

\section{Conclusion}

Fish scarcity and unaffordability is a real risk to food vulnerability in Senegal whose population is highly dependent on seafood products. While available data in the literature have highlighted generalized overexploitation of the major fish stocks for years, our analysis has shown significant upward trends in average prices and the CPI for fish. We found that during the last two decades, the population has been facing long-term increases in fish prices with significant seasonal variability. In such a harmful context, the poorest households have been trying to respond as best as they could by substituting different fish products, diversifying their animal protein sources, and changing their culinary habits.

Potential solutions against fish shortage on the domestic market have to be found in different directions. While emphasizing the associated constraints, we suggest that priority should mainly be given to the implementation of effective fisheries management policies, the promotion of responsible fish harvests and utilization and development of a productive aquaculture sector. The future actions should also look into the considerable challenges that may undermine the ability of the population and the authorities to successfully implement long-term efficient adaptive strategies. These challenges are linked to the context of rapid population growth and urbanization, pessimistic perspectives on global fish availability, and low purchasing power that may exacerbate social inequality in fish consumption.

Acknowledgments. The authors thank Professor Mafaniso Hara, Fisheries Economist at the Institute for Poverty, Land and Agrarian Studies (PLAAS), Faculty of Economic and Management Sciences, University of the Western Cape, South Africa. He kindly accepted to revise and provide significant language edits in the manuscript.

\section{References}

Akande G, Diei-Ouadi Y. Post-harvest losses in small-scale fisheries: case studies in five sub-Saharan African countries. FAO Fisheries and Aquaculture Technical Paper No. 550, FAO, Rome, 2010, 72 p.

Bundy A, Chuenpagdee R, Boldt JL, Borges MF, Camara ML, Coll M, Diallo I, Fox C, Fulton EA, Gazihan A, Jarre J, Jouffre D, Kleisner KM, Knight B, Link J, Matiku PP, Masski H, Moutopoulos DK, Piroddi C, Raid T, Sobrino I, Tam J, Thiao D, Torres MA, Tsagarakis K, Van der Meeren GI, Shin YJ. 2017. Strong fisheries management and governance positively impact ecosystem status. Fish Fish 18: DOI: 10.1111/faf.12184.

Christensen V, et al. Trends in fish biomass off Northwest Africa, 1960-2000, in: P. Chavance et al. (Eds.), Pêcheries maritimes, écosystèmes et sociétés en Afrique de l'Ouest: un demi-siècle de changement. Actes du symposium international de Dakar (Sénégal) du 24 au 28 juin2002. Collection des rapports de recherche halieutique, ACP-UE, no. 15, Vol. 1, 2002, pp. 377-386.

Diei-Ouadi Y, Mgawe YI. Post-harvest fish loss assessment in smallscale fisheries: a guide for the extension Officer. FAO Fisheries and Aquaculture Technical Paper No. 559, FAO, Rome, 2011, 93 p.

Failler P, Lecrivain N. L'impact des accords de pêche sur l'approvisionnement des marchés des pays en développement, DFID Policy Research Publication, London, 2003. 
FAO. Code of conduct for responsible fisheries, FAO, Rome, 1995, $41 \mathrm{p}$.

FAO. Status summary for small pelagic stocks in the Northern Area of the Eastern Central Atlantic - CECAF, Main outcomes of the FAO Working Group on the Assessment of Small Pelagic Fish off Northwest Africa 2012-2015, Seventh Session, Tenerife, Spain, 2015, 17 p.

FAO. The State of World fisheries and aquaculture. Contributing to food security and nutrition for all, Rome, 2016, 200 p.

FAO. Reduction of fish food loss and waste, Sub-Committee on Fish Trade, Sixteenth Session, Busan, Republic of Korea, 2017, 6 p.

Garcia SM, Grainger RJR. 2005. Gloom and doom? The future of marine capture fisheries. Philos Trans $R$ Soc B 360: 21-46.

Gephart JA et al. 2016. Vulnerability to shocks in the global seafood trade network. Environ Res Lett 11: 035008.

Gordon A, Finegold C, Crissman CC, Pulis A. Fish production, consumption, and trade in Sub-Saharan Africa: a review analysis, WorldFish Center, 2013, 51 p.

Hall SJ, Delaporte A, Phillips MM, Beveridge M, Keefe MO. Blue Frontiers: managing the environmental costs of aquaculture, WorldFish Center, 2011.

Lam VWY et al. 2012. Climate change impacts on fisheries in West Africa: implications for economic, food and nutritional security. Afr J Mar Sci 34: 103-117.

Laurans $M$ et al. 2004. Changes in the trophic structure of fish demersal communities in West Africa in the three last decades. Aquat Living Res 17: 163-173.

Leport J. Dynamiques de changement des modèles alimentaires: le cas du poisson à Dakar, Thèse de doctorat, Université de Toulouse 2-Jean Jaurès, Toulouse, France, 2017, 558 p.

Mankor A. Etude des déterminants de la consommation urbaine en viandes en Afrique de l'Ouest: l'exemple de Dakar, Thèse de doctorat, Ecole Nationale Supérieure Agronomique de Montpellier, 2001, 286 p.

Poulain P. Sociologies de l'alimentation, PUF, 2002, 287 p.

Thiao D. Un système d'indicateur de durabilité des pêcheries côtières comme outil de gestion intégrée des ressources halieutiques Sénégalaises, Doctorate thesis in Economics (Integrated Sustainable Development), Université de Versailles Saint Quentin-enYvelines, 2009, $297 \mathrm{p}$.

Thiao D, Laloë F. 2012. A system of indicators for sustainability: an example from the Senegalese fisheries. Mar Res Econ 27: 267-282.

Thiao D, Chaboud C, Samba A, Laloë F, Cury P. 2012. Economic dimension of the collapse of the "false cod" (Epinephelus aeneus) in a context of ineffective management of the small-scale fisheries in Senegal. Afr J Mar Sci 34: 305-311.

Thiao D, Mbaye A, Dème M, Diadhiou HD. 2017. Focusing on monofilament nets while overlooking the priorities of artisanal fisheries governance in Senegal. Afr J Mar Sci 39: 339-348.

Tsikliras AC, Polymeros K. 2014. Fish market prices drive overfishing of the "big ones". PeerJ 2: e638, DOI: 10.7717/ peerj. 638 .

UEMOA. Indice harmonisé des prix à la consommation des pays membre de l'UEMOA: théorie et pratique, UEMOA, AFRISTAT, EUROSTAT, EUROCOST, 1996, 325 p.

UNEP. Integrated assessment of trade liberalization and trade-related policies: a country study on the fisheries sector in Senegal, United Nations Publication, New York, 2002, 102 p.

Zuberi T, Thomas KJA. Demographic projections, the environment and food security in Sub-Saharan Africa. Working Paper 2012-001, Regional Bureau for Africa, United Nations Development Programme, 2012.

Cite this article as: Thiao D, Leport J, Ndiaye B, Mbaye A. 2018. Need for adaptive solutions to food vulnerability induced by fish scarcity and unaffordability in Senegal. Aquat. Living Resour. 31: 25 